Int. J. Curr. Res. Med. Sci. (2017). 3(8): 1-7

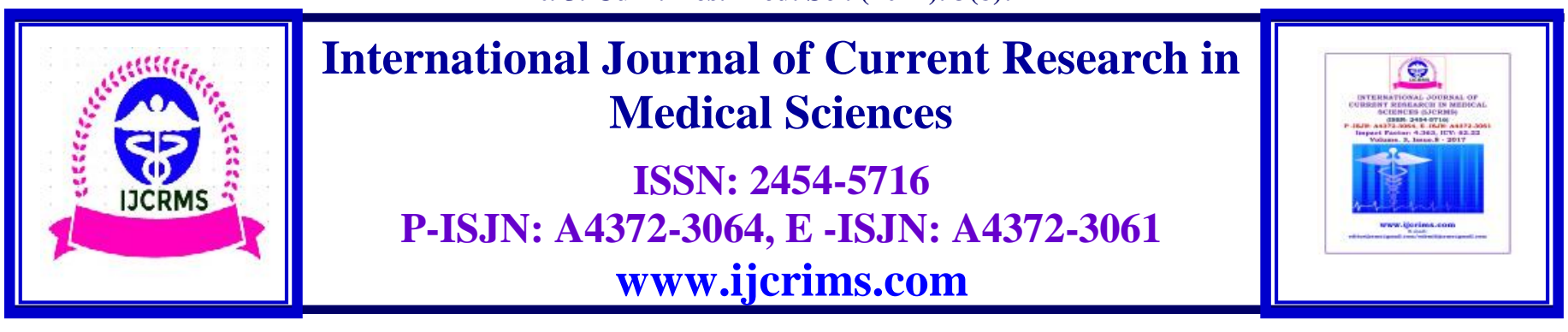

\title{
Effect of salbutamol nebulization in transient tachypnea of newborn
}

\author{
*Amanpreet Kaur, **Pardeep Singh Kahlon, ***Karnail Singh, ***MS Pannu \\ *Junior Resident, **Assistant Professor, ***Professor, Department of Paediatrics, Govt. Medical College, \\ Amritsar, India, 143001 \\ Corresponding Author: Dr. Pardeep Singh Kahlon, Assistant Professor, Department of Paediatrics, \\ Govt. Medical College, Amritsar, India, 143001 \\ E-mail:docpsk@yahoo.com
}

\begin{abstract}
Background: Transient tachypnea of newborn (TTN) is a parenchymal lung disease present in neontes usually within 6 hours of life. Signs of TTN usually persist for 12-24 hours in mild disease but can last upto 72 hours in more severe cases. In severe cases of TTN, complications such as pneumothorax, need for extracorporeal membrane oxygenation, and death have been reported.

Objective: To study the effect of single dose of salbutamol nebulization in TTN administered at diagnosis and assess its efficacy at 30minutes, 1 hour and 4 hours post nebulization and the side effects if any at 4 hours

Materials and methods:

Study design: Double blind prospective placebo controlled study, one dose of inhaled salbutamol or normal saline solution was administered to 50 newborns each with gestational age of 35 to 41 weeks and diagnosed as TTN according to clinical and radiological features. Setting: Pediatrics Department, Bebe Nanki Mother and Child Care Centre, Government Medical College, Amritsar. Participants:100 newborns. Outcome variables: TTN score, oxygen saturation, respiratory rate and average duration of hospital stay.

Results: After one dose of salbutamol nebulization, the TTN score, respiratory rate, oxygen saturation and duration of hospitalization did not decrease significantly when compared with the normal saline group ( $\mathrm{p}$ value $>0.05$ ). No side effects like tachycardia, hypokalemia and hyperglycemia were noted in salbutamol group when compared to normal saline group.

Conclusion: Inhaled salbutamol treatment did not show any effect on early resolution of symptoms and early discharge of babies.
\end{abstract}

Keywords: TTN, Salbutamol nebulization. 


\section{Introduction}

Transient tachypnea of newborn (TTN) is parenchymal lung disease. It is the benign selflimited condition resulting from delayed resorption of foetal lung fluid ${ }^{1}$. This condition is characterised by:-

- $\quad$ Tachypnea with signs of mild respiratory distress including retractions, grunting, nasal flaring and mild cyanosis.

- Decreased oxygen saturation alleviated by supplemental oxygen with $\mathrm{FiO}_{2}$ less than $40 \%{ }^{2}$.

It is the common cause of respiratory distress in the immediate new born period. In a review of 33,289 term deliveries (37 to 42 weeks), the incidence of TTN was 5.7 per 1000 births $^{3}$.

Infants with TTN present within the first 6 hours of life. Signs of TTN usually persist for 12-24 hours in mild disease but can last up to 72 hours in more severe cases ${ }^{2}$. Although it is self limited condition, there is an increase data to suggest that TTN increases risk for developing a wheezing syndrome early in the life ${ }^{4}$. During late gestation, in response to increased concentrations of catecholamines and other hormones, the mature lung epithelium switches from actively secreting chloride and liquid into the air spaces to actively reabsorbing sodium and liquid ${ }^{5-6}$. Increased oxygen tension at birth enhances the capacity of the epithelium to transport sodium and increases gene expression of the epithelial sodium channel $(\mathrm{ENaC})$ followed by transport into the interstitum via basolateral nat/k+-ATPase and passive movement of chloride and water through the par cellular and intracellular pathways ${ }^{6}$.Epithelial sodium channels play a crucial role in lung liquid clearance at birth. In fact, the first evidence of involvement of these receptors came from measurements of an amiloride-induced drop in potential difference between the nasal epithelium and subcutaneous space in newborns. Gowen et $\mathrm{al}^{7}$ demonstrated that this potential difference was reduced in infants with TTN (suggesting a defect in sodium trans-port), and recovery from TTN in 1 to 3 days was associated with an increase in potential difference to normal level. Passive resorption of liquid also occurs after birth because of differences among the oncotic pressure of air spaces, interstitium, and blood vessels. The majority of water transport across the apical membrane is thought to occur through aquaporin 5 (AQP5) water channels ${ }^{8}$.

\section{Materials and Methods}

This prospective study was conducted on 100 new borns diagnosed with TTN admitted in the Paediatrics Department of Bebe Nanki Mother and Child Care Centre attached to Government Medical College and Hospital, Amritsar. The study criteria of patients are described as follows-

\section{Selection of cases}

\section{Inclusion criteria}

1. Neonates (35 to 41 weeks of gestation) diagnosed as TTN (according to Rawling and Smith Criteria)

\section{Exclusion criteria}

1. Premature neonates [ $<35$ weeks]

2. Neonates requiring respiratory support in form of CPAP and mechanical ventilation.

3. Exclusion of other known respiratory disorders like:

- $\quad$ Meconium Aspiration- irregular pattern of increased density throughout lung, no meconium staining of skin

- Respiratory Distress Syndrome- having reticulo-granular pattern in $\mathrm{x}$-rays picture, premature neonates, no surfactant therapy.

- Congenital heart disease-having murmur, signs of heart failure.

- Birth asphyxia-history suggestive of intrauterine asphyxia, delayed cry at birth.

TTN was diagnosed according to Rawlings and smith $^{9}$ which is based on the radiologic and clinical findings-

1] Early(within 6 hours of birth) onset of tachypnea [in uneventful late preterm(3536weeks)or term newborn] 
2] Persistence of tachypnea sometimes with retaractions, or expiratory grunting and, occasionally, cyanosis that is relieved by minimal oxygen supplementation.

3] Chest generally sounds clear without rales or rhonchi.

Chest radiograph shows:

- $\quad$ Prominent pulmonary vascular markings.

- $\quad$ Fluid in the interlobar fissure.

- Flat diaphragms and rarely pleural effusion.

\section{- Hyperaeration}

Blood sugar and electrolytes (serum sodium and potassium levels) were also determined as the base line recording. Two solutions, of which one containing salbutamol and another containing normal saline were prepared.There was no detectable difference in colour, smell, or other physical properties between these two solutions. After diagnosing a patient of TTN, candidates were allotted with a study number and his/her TTN score. Respiratory rate, heart rate and oxygen saturation were recorded. These study numbers corresponded to the order of the patient entering the study. Simple random sampling was done according to a computer generated random number table on a master list to one of the two solutions i.e. salbutamol solution and normal saline solution. Then neonate was nebulised with either of the solution. Both the caregiver and the subject were blinded regarding the drug used for nebulization. sample was collected again at 4 hours after nebulization for serum potassium and glucose levels.

Patients received one nebulized dose of either $3 \mathrm{ml}$ $0.9 \%$ normal saline solution(placebo) or the solution of salbutamol $3 \mathrm{ml}$ (asthalin solution is $5 \mathrm{mg} / \mathrm{ml}$ ) in a normal saline $0.9 \%$ solution. The standard dose of salbutamol was calculated according to the weight of the baby i.e. $0.15 \mathrm{mg} / \mathrm{kg}$. Solution was given with jet type nebulizer along with continuous flow of oxygen at 5 to 6 litres/min. Administration of the solution was performed by nurse on duty. The dose was administered over 15 minutes, and vital signs were monitored at 30minutes, 1 hour and 4 hours after nebulization. Intravenous fluids were given as $60 \mathrm{ml} / \mathrm{kg}$ in enrolled babies and additional oxygen inhalation was given at 2 litres/min through nasal prongs after the nebulization in both cases and control group.

30minutes, 1 hour and 4 hours after nebulization, following parameters were noted like :

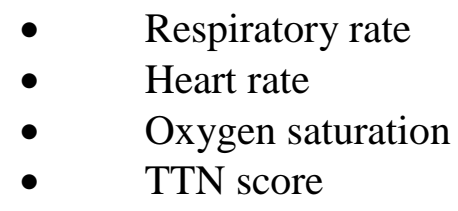

4 hours after nebulization - blood sample collected for-

- $\quad$ Serum potassium

- Blood Glucose levels

\section{Results}

In the present study $65 \%$ of the patients were males and $35 \%$ were females( figure 1). The mean age of presentation in hours was $3.80 \pm 1.77$ hours. We also analysed the patient characteristics like gender distribution, age at which the neonate presented to hospital and gestational age (in weeks) at birth. There were no significant differences between the treatment and control groups with regard to any of the following: gestational age $(38.35 \pm 1.22$ vs $38.52 \pm 1.26)$, birth weight, age at admission to hospital $(3.80 \pm 1.77$ in cases and $3.50 \pm 1.77$ in control group), initial respiratory rate $(73.4 \pm 4.5$ vs $72.2 \pm 4.8)$ and oxygen saturation on admission $(94.7 \pm 1.6$ vs $94.82 \pm 1.76$ ). Figure and table 2 shows the result of nebulization in salbutamol and normal saline group in TTN score. There was no significant difference in between two group statistically. Figure and table 3 shows the respiratory rate between two groups after nebulization, statistically it is not significant difference. 
Int. J. Curr. Res. Med. Sci. (2017). 3(8): 1-7

Table 1 -TTN SCORE- ${ }^{10}$

\begin{tabular}{|l|l|l|l|l|}
\hline SCORE & 0 POINT & 1 POINT & 2 POINT & 3 POINT \\
\hline Expiratory grunt & None & Intermittent & Continuous & - \\
\hline Subcostal retractions & None & Mild & Moderate & Severe \\
\hline Cyanosis & None & At extremities & Central & - \\
\hline Nasal flaring & None & Mild & Moderate & Severe \\
\hline $\begin{array}{l}\text { Supraclavicular } \\
\text { retractions }\end{array}$ & None & Mild & Moderate & Severe \\
\hline
\end{tabular}

Figure 1 shows the distribution of neonates according to gender

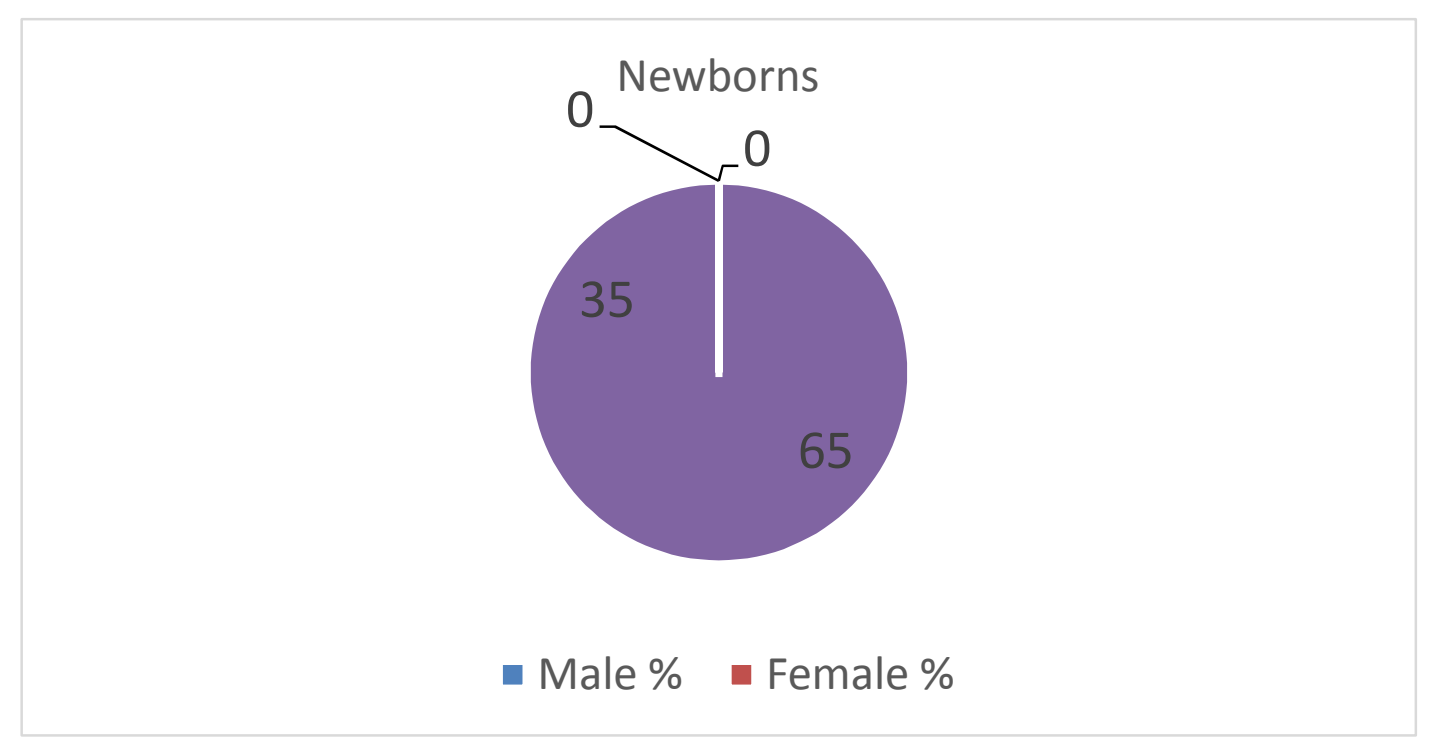

Figure 2: shows the TTN score after nebulization

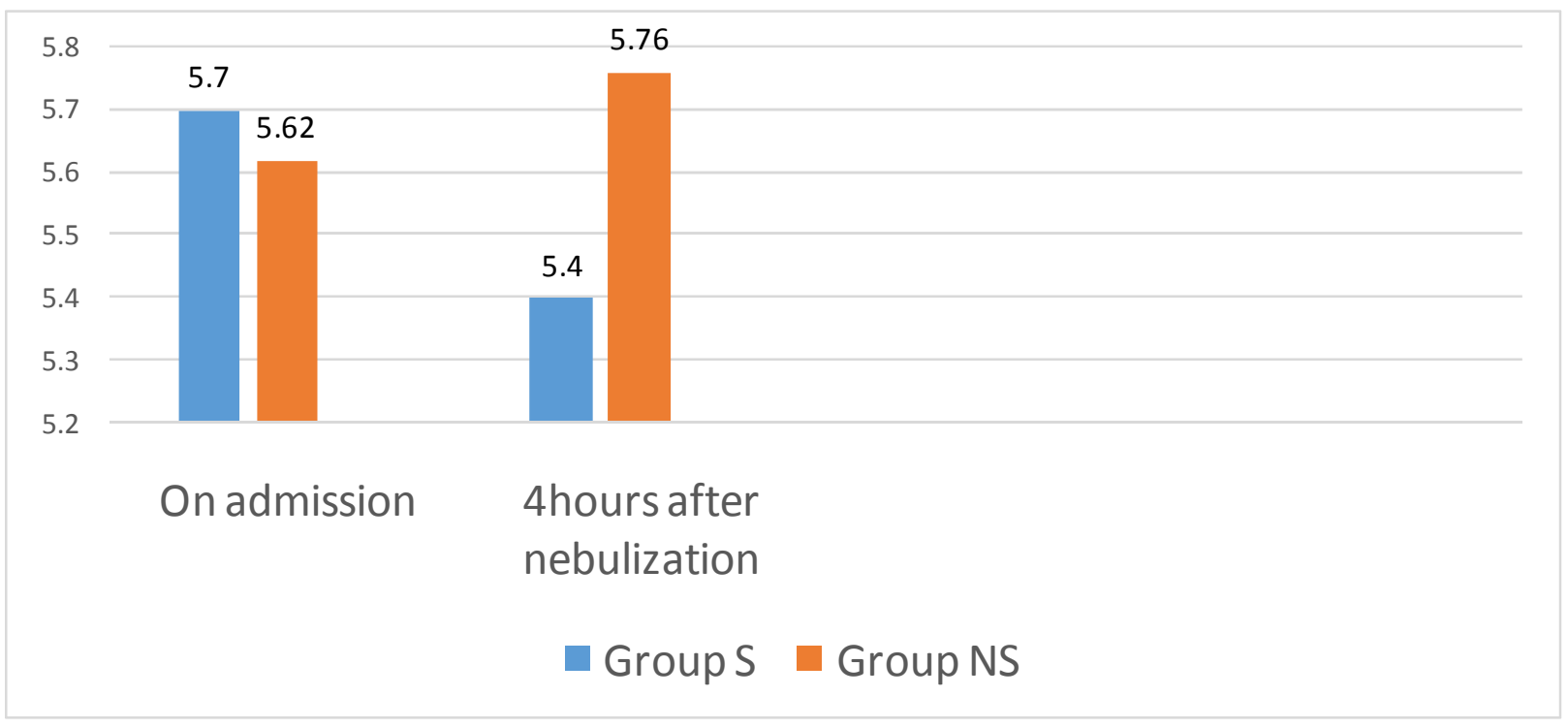

Table 2: Different values of TTN score in groups at different time interval 
Int. J. Curr. Res. Med. Sci. (2017). 3(8): 1-7

\begin{tabular}{|c|c|c|c|c|c|}
\hline \multirow{2}{*}{ TTN SCORE } & \multicolumn{2}{|c|}{ Group S } & \multicolumn{2}{|c|}{ Group NS } & \multirow[t]{2}{*}{ p-value } \\
\hline & Mean & SD & Mean & SD & \\
\hline On admission & 5.700 & 1.0351 & 5.620 & 1.1229 & 0.712 \\
\hline $30 \mathrm{~min}$ after nebul & 5.720 & 1.0506 & 5.740 & 1.1214 & 0.927 \\
\hline 1 hour after nebulization & 5.500 & 1.3286 & 5.700 & 1.1112 & 0.416 \\
\hline 4 hours after nebulization & 5.400 & 1.4142 & 5.760 & 1.1528 & 0.166 \\
\hline
\end{tabular}

Figure 3 shows the respiratory rate in different groups

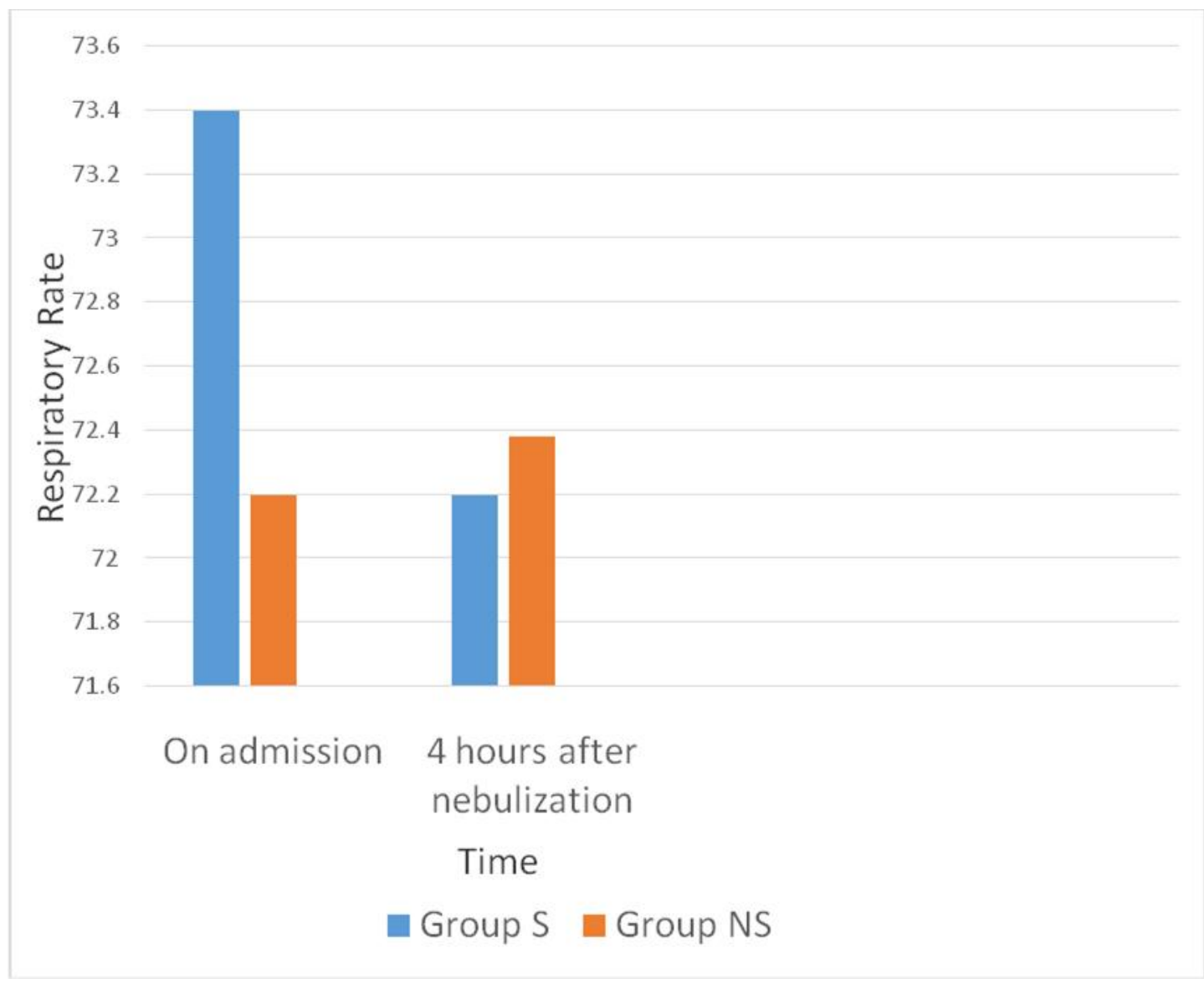

Table 3: Different values of mean (with standard deviation) of respiratory rate in groups at different time interval

\begin{tabular}{|c|c|c|c|c|c|}
\hline \multirow{2}{*}{ Respiratory rate } & \multicolumn{2}{|c|}{ Group $\mathrm{S}$} & \multicolumn{2}{|c|}{ Group NS } & \multirow{2}{*}{ p-valu } \\
\hline & Mean & $\pm \mathrm{SD}$ & Mean & $\pm \mathrm{SD}$ & \\
\hline On admission & 73.400 & 4.5266 & 72.200 & 4.8865 & 0.206 \\
\hline 30 min after nebulization & 73.500 & 4.2342 & 72.420 & 5.2648 & 0.261 \\
\hline 1 hour after nebulization & 72.900 & 4.3577 & 72.280 & 5.8311 & 0.548 \\
\hline 4 hours after nebulization & 72.200 & 5.1429 & 72.380 & 5.5065 & 0.866 \\
\hline
\end{tabular}


Int. J. Curr. Res. Med. Sci. (2017). 3(8): 1-7

Present study was undertaken to see the effect of salbutamol nebulization in transient tachypnea of newborn in the following parameters.

\section{Clinical characteristics}

\section{Respiratory rate:}

In our study the mean respiratory rate of Salbutamol Group (cases) before nebulization was $73.400 \pm 4.5$ and it did not decrease significantly 4 hours after nebulization (72.2 \pm 5.1$)$. $\mathrm{P}$ value was 0.866 ,which was statistically not significant when we compared it with the respiratory rate of neonates in the control group. This is in contrast to results observed by Armangil $\mathrm{D}$ et $\mathrm{al}^{10}$ which showed significant decrease in respiratory rate $(70 \pm 19$ vs $62 \pm 14)$ and by Venkatamurthy et $\mathrm{al}^{11}$ respiratory rate was $(75.74 \pm 5.93$ and $66.31 \pm 7.41)$ before and after nebulization respectively. Myo Jing Kim et $\mathrm{al}^{12}$ showed that there was decrease in the duration of tachypnea after treatment with salbutamol nebulization than in the control group $(31.3 \pm 23.7 \mathrm{~h}$ vs. $53.5 \pm 56.8 \mathrm{~h}$, respectively); but this difference was not significant $(\mathrm{P}=0.37)$. However, no differences in the maximum respiratory rates during the acute period after inhalation treatment were observed between the salbutamol inhalation group and the control group.

\section{TTN score:}

In our study the mean TTN score before and after 4 hours nebulization in salbutamol group was $(5.7 \pm 1.0$ and $5.40 \pm 1.41)$ and in control group $(5.66 \pm 1.12$ and $5.76 \pm 1.15)$ and it did not decrease significantly with p-value of 0.16 . The mean TTN score observed before and after salbutamol nebulization in other studies like Armangil D et al is (8 vs. 2.5) and Venkatamurthy et al $(8.26 \pm 0.44$ vs. 5.77 \pm 2.07 ) showed a decrease in TTN score after nebulization.

\section{Oxygen Saturation:}

There was no significant difference with the resultant p-value of 0.32 in the oxygen saturation between the salbutamol $(94.78 \pm 1.64$ on admission and 96.24 after nebulization) and normal saline group $(94.82 \pm 1.76$ on admission and $95.9 \pm 1.88)$.

\section{Average duration of the hospital stay (in days):}

Our analysis showed that patients treated with either solution had no significant difference in terms of the duration of hospitalization with $\mathrm{p}$ value of $>0.05$, these results were in accordance with the study done by Myo Jing Kim et al which also showed that the duration of hospitalization was similar between the 2 groups $(8.5 \pm 3.9$ days vs. $8.8 \pm 3.2$ days in treatment and control group respectively).

\section{Short term/immediate adverse effects:}

Our analysis showed no incidence tachycardia (>180/min) after salbutamol nebulization when compared with normal saline group with $\mathrm{p}$ value 0.008. Heart rate evaluated after salbutamol nebulization $(137 \pm 7.8)$ showed no significant increase when compared with normal baseline evaluation at the time of admission (135 \pm 9.3$)$. Similar results in heart in both treatment and control group after nebulization were shown by the studies done by the Armangil D et aland Venkatamurthy et al.

\section{Specific adverse effect:}

Our study showed no significant change in the serum potassium levels and blood glucose levels after salbutamol nebulization when they were compared with the normal saline group.

Studies done by Armangil et al also showed that after nebulization there was no significant change in serum potassium levels in salbutamol and normal saline group respectively.

\section{Conclusion}

Thus it can be concluded from the present study that $65 \%$ of the patients were males and $35 \%$ were females. Group which was nebulized with salbutamol did not show statistically significant improvement in the respiratory rate, TTN score and oxygen saturation when compared with the control group $(>0.05)$. There were no immediate as well as specific side effects observed in the 
Int. J. Curr. Res. Med. Sci. (2017). 3(8): 1-7

salbutamol group. Average duration of hospital stay (in days) was almost similar between two groups. Thus, we conclude that our results did not show any significant effect of salbutamol nebulization (single dose) in early resolution of symptoms and early discharge of the baby. There is a need to explore the subject further taking larger sample size with change of dosing schedule to show the efficacy of salbutamol, if any, in treatment of the TTN.

\section{Source of funding: Nil}

Conflict of interest: None declared

\section{References}

1. Avery ME, Gatewood OB, Brumley GE. Transient tachypnea of newborn. Possible delayed resorption of fluid at birth. Am J Dis Child. 1966 Apr; 111(4):380-5.

2. Kienstra KA. Transient tachypnea of the newborn. In: Cloherty JP, Eichenwald EC, Hansen AR, Stark AR. Manual of neonatal care. $7^{\text {th }}$ ed. New Delhi. Wolters Kluwer, 2011, p. 403-5.

3. Morrison JJ, Resnnie JM, Milton PJ. Neonatal respiratory morbidity and mode of delivery at term: influence of timing of elective caesarean section. Br J Obstet Gynaecol 1995 Feb; 102(2): 101-6.

4. Liem JJ, Huq SI, Ekuma O,Becker AB, Kozyrskyj AL. Transient tachypnea of newborn may be an early manifestation of wheezing syndrome. J Paediatr 2007 Jul; 15(1): 29-33.
5. Aslan E, Tutdibi E, Martens S, Han Y, Monz D, Gortner L. Transient tachypnea of the newborn (TTN): a role for polymorphisms in the beta-adrenergic receptor (ADRB) encoding genes. Acta Paediatr. 2008 Oct; 97(10):1346-50.

6. Birnkrant DJ, Picone C, Markowitz W, El khwad M, Shen WJ, Tafari N. Association of the transient tachypnea of newborn and childhood asthma. Pediatr Pulmonol. 2006 Oct;41(10):978-84.

7. Ramachandrappa A, Jain L. Elective cesarean section: its impact on neonatal respiratory outcome. Clin Perinatol. 2006; 35(2): 373-393.

8. Miller LK, Calenoff L, Boehm JJ, Riedy MJ. Respiratory distress in the newborn. JAMA 1980;243(11):1176-9.

9. Ambalavan N, Carlo WA. Transient tachypnea of newborn. In: Kliegman RM, Stanton BF, St. Geme JW, Schor NF, Behrman RE. Nelson Textbook of Pediatrics. 19th ed. New Delhi: Elsevier: 2012, p. 590.

10. Armangil D, Yurdakok M, Korkmaz A, Yigit S. Tekinalp G. Inhaled salbutamol for the treatment of transient tachypnea of newborn. J Paeditr 2011 Sep; 159(3): 398-403.

11. Venktamurthy M, Hemachandra Reddy K, Murali SM. Salbutamol nebulization, a CostEffective method in treating wetlung. International Journal of Health Information and Medical Research 2014; 1(1): 5-8.

12. Kim MJ, Yoo JH, Jung JA, Byun SY. The effect of inhaled albuterol in transient tachynea of newborn. Allergy Asthma Immunol Res 2014Mar; 6(2): 126-30.

\begin{tabular}{|c|l|}
\hline \multicolumn{2}{|c|}{ Access this Article in Online } \\
\hline 口 & Website: \\
& www.ijcrims.com \\
& Subject: \\
\hline Quick Response Code & \\
\hline
\end{tabular}

How to cite this article:

Amanpreet Kaur, Pardeep Singh Kahlon, Karnail Singh, MS Pannu. (2017). Effect of salbutamol nebulization in transient tachypnea of newborn. Int. J. Curr. Res. Med. Sci. 3(8): 1-7.

DOI: http://dx.doi.org/10.22192/ijcrms.2017.03.08.001 